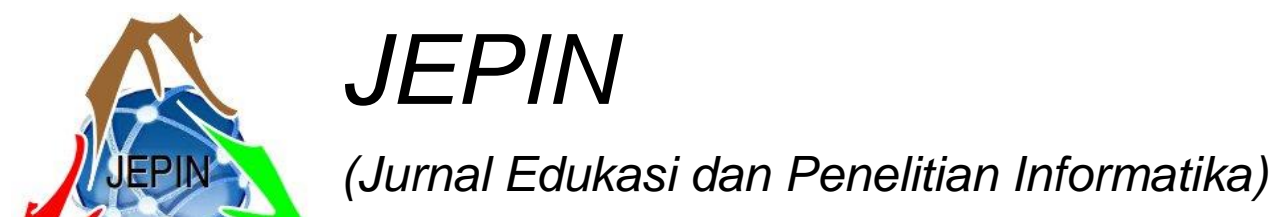

Vol. 4

No. 2

ISSN(e): 2548-9364 / ISSN(p) : 2460-0741

Desember

2018

\title{
Sistem Kelas Virtual dan Pengelolaan Pembelajaran berbasis 3-Dimensional Virtual World
}

\author{
Adhi Rizal $^{\# 1}$, Riza Ibnu Adam ${ }^{\# 2}$, Susilawati ${ }^{\# 3}$ \\ ${ }^{\#}$ Fakultas Ilmu Komputer, Universitas Singaperbangsa Karawang \\ Jl. HS.Ronggo Waluyo, Puseurjaya, Telukjambe Timur, Kabupaten Karawang, Jawa Barat \\ ${ }^{1}$ adhi.rizalestaff.unsika.ac.id \\ ${ }^{2}$ riza.adamestaff.unsika.ac.id \\ ${ }^{3}$ susilawati.soburestaff.unsika.ac.id
}

\begin{abstract}
Abstrak - Penelitian ini bertujuan untuk mengembangkan dan menerapkan sistem kelas virtual berbasis dunia virtual 3 dimensi (3D). Kelas virtual dikembangkan berdasarkan framework pengembangan aplikasi ADDIE dengan meintegrasikan LMS Moodle, singularity viewer, SLOODLE, dan multi-user 3D application server OpenSimulator. Objekobjek yang ada pada kelas di dunia nyata direpresentasikan oleh objek 3D. Peserta didik dapat berinteraksi dengan objek-objek yang ada dalam kelas virtual untuk melaksanakan kegiatan pembelajaran. Pengujian kelas virtual dilakukan dengan cara menerapkannya untuk digunakan secara langsung oleh peserta didik dalam kegiatan pembelajaran. Pengujian dilakukan berdasarkan dua kriteria, yaitu evaluasi hasil belajar peserta didik dan uji penerimaan pengguna menggunakan Technology Acceptance Model (TAM). Hasil evaluasi hasil belajar menunjukan bahwa penggunaan kelas virtual tidak berpengaruh terhadap hasil belajar. Walaupun demikian, hasil uji penerimaan pengguna menunjukan bahwa kelas virtual dapat memberikan kepuasan dan dapat diterima untuk digunakan oleh peserta didik dalam proses pembelajaran.
\end{abstract}

Kata kunci - kelas virtual, 3D virtual world, ADDIE, Hasil belajar, TAM

\section{PENDAhUluan}

Lingkungan belajar yang bersifat dinamis dapat diwujudkan dengan memanfaatkan teknologi. Hal ini disebabkan karena teknologi komputer dan infrastruktur jaringan sudah sangat berkembang. Beberapa perkembangan lingkungan belajar yang menerapkan media elektronik serta teknologi informasi dan komunikasi dalam pendidikan (e-learning) diantaranya mencakup pembelajaran multimedia, technologyenhanced learning (TEL), computer-based instruction (CBI), computer-based training (CBT), computer-assisted instruction atau computer-aided instruction (CAI), internet-based training (IBT), web-based training (WBT), online education, virtual education, virtual learning environments (VLE) (disebut juga platform pembelajaran), mLearning, dan digital educational [1]. Dengan adanya teknologi tersebut, maka sangat dimungkinkan teknik dan cara pada proses maupun lingkungan pembelajaran dapat berubah. Hal ini disebabkan karena e-learning dapat memberikan kebebasan untuk peserta didik dengan pengajar atau sesama peserta didik dalam berinteraksi tanpa terbatas waktu dan ruang belajar.

Terdapat banyak penelitian yang menyatakan bahwa pendekatan pembelajaran dengan berpusat pada peserta didik yang belajar dari dunia nyata (kontekstual) dengan bantuan sumberdaya digital memiliki banyak kelebihan [2], [3]. Namun, meskipun proses pembelajaran yang dilakukan dengan memanfaatkan teknologi dirasa cukup menjanjikan, namun hal ini masih jauh dari pembelajaran berbasis teknologi ideal yang dapat disebut sebagai "smart learning" [2]. Lingkungan "smart learning" tidak hanya memberikan peserta didik kemudahan akses terhadap sumberdaya digital dan berinteraksi dengan sistem pembelajaran di mana saja dan kapan saja tetapi juga harus dapat memberikan petunjuk/arahan, perangkat atau peralatan pendukung, atau sugesti positif dalam pembelajaran di waktu, tempat, serta bentuk yang tepat [2]. Terlebih lagi di abad 21 ini tantangan dan kebutuhan terhadap dampak perkembangan teknologi mengubah perilaku dan kebiasaan manusia dalam menggunakan teknologi untuk berkomunikasi, berinteraksi, dan belajar [4]. Hal ini mengakibatkan meningkatnya kebutuhan akan kemampuan khusus untuk mencapai tujuan atau mengatasi masalah tertentu [5]. Untuk mengatasi hal ini, pendidikan membutuhkan penekanan terhadap pendekatan pembelajaran yang dapat membentuk keterampilan kognitif untuk mengatasi permasalahan dengan menggunakan pengetahuan yang sudah ada maupun yang baru [6].

Salah satu upaya yang dapat dilakukan untuk menjawab tantangan dan permasalahan tersebut adalah adalah dengan menerapkan paradigma baru pada metode dan 
model pembelajaran, misalnya pembelajaran aktif dan pembelajaran yang berpusat pada peserta didik. Hal ini dapat diupayakan dengan menerapkan inovasi teknologi pembelajaran seperti VLE [7]. VLE yang dapat disebut juga Course Management System (CMS) berbasis 3 dimensi (3D) merupakan salah satu jenis e-learning yang marak diterapkan pada proses pembelajaran [8], [9].

VLE merupakan objek yang dibangun dan dikembangkan dari komputer, memiliki sifat yang tidak terbatas, seperti permainan (game), dan biasanya dilengkapi dengan grafis 3 dimensi yang menyerupai dunia nyata [10]. Pengguna dapat membuat karakter yang disebut sebagai avatar yang merepresentasikan dirinya sendiri di VLE dan berpartisipasi dalam berbagai jenis kegiatan/aktivitas. Pemanfaatan multi-channel (komunikasi yang menggunakan banyak jalur/saluran) memungkinkan pengguna untuk berkomunikasi dan menunjukan emosi (dengan adanya bahasa tubuh) melalui internet di dalam dunia yang mirip dengan dunia nyata [11].

VLE menyediakan banyak fitur khusus dan unik. Oleh karena itu terdapat banyak peluang untuk memanfaatkannya di dunia pendidikan. Terlepas dari fakta bahwa VLE memiliki tujuan utama sebagai sarana hiburan, pemanfaatan VLE juga memiliki potensi yang besar untuk menjadi platform pendidikan yang inovatif di masa depan dengan cara melibatkan peserta didik dengan pembelajaran eksperimental yang mirip dengan dunia nyata. Lebih dari itu, sudah banyak institusi pendidikan yang menunjukan bahwa lingkungan virtual berbasis 3D dapat diterapkan di aktivitas pembelajaran pembelajaran [8], [12].

Berdasarkan latar belakang yang telah dipaparkan, maka rumusan masalah pada penelitian ini adalah belum adanya studi yang bertujuan untuk menginvestigasi pengaruh sistem kelas virtual 3 dimensi terhadap hasil belajar peserta didik dan kurangnya motivasi atau minat peserta didik terhadap proses pembelajaran. Oleh karena itu penelitian ini mengusulkan suatu sistem pembelajaran berbasis komputer dalam bentuk kelas virtual yang dapat digunakan sebagai sarana pendukung dan pelengkap ruangan kelas yang sebenarnya. Konsep sistem pembelajaran yang akan dikembangkan adalah VLE menggunakan perangkat lunak berbasis Learning Management System (LMS) dan 3D Virtual world. Konsep virtual learning yang diimplementasikan dalam bentuk 3 dimensi memiliki kelebihan dibandingkan konsep pembelajaran formal pada umumnya. Dengan demikian konsep e-learning yang terkesan monoton dan membosankan diharapkan dapat menjadi lebih hidup dan interaktif karena pada konsep 3D virtual learning pihak pengajar dan peserta didik harus bersama-sama melakukan kegiatan pembelajaran.

\section{KAJIAN LITERATUR}

\section{A. Penelitian Terkait}

Beberapa penelitian mengenai VLE sudah pernah dilakukan sebelumnya. Penelitian yang dilakukan oleh [7] menunjukan bahwa penerapan 3D-VLE dapat meningkatkan motivasi dan efisiensi proses pembelajaran. Kemudian penelitian serupa juga dilakukan oleh [13] yang bertujuan untuk menginvestigasi potensi dari MultiuserVirtual Environement (MUVE) sebagai lingkungan pembelajaran untuk ilmu pengetahuan alam, teknologi, dan matematika. Penelitian ini menunjukan bahwa peserta didik yang menggunakan MUVE sebagai alternatif dari proses pembelajaran tradisional memperoleh nilai hasil belajar yang lebih tinggi dibandingkan dengan peserta didik dengan proses pembelajaran tradisional. Selain itu penelitian terkait pengembangan VLE juga dilakukan oleh [14]. Penelitian ini menunjukan bahwa VLE merupakan lingkungan belajar yang baik untuk diterapkan pada $21^{s t}$ century learning, sehingga meningkatkan motivasi dan hasil belajar peserta didik.

\section{B. 3D Virtual world}

3D Virtual world atau dunia virtual 3 dimensi merupakan lingkungan yang dihasilkan oleh komputer di mana pengguna dapat bereksplorasi dan berinteraksisesuai dengan keinginannya secara bebas. Konsep dunia virtual 3D ini mencakup OpenSimulator, 3D Virtual Campus Tours, Azivia, dan Second life, di mana avatar 3D merepresentasikan setiap pengguna yang dapat berinteraksi satu sama lain di kehidupan sosial secara virtual [15].

\section{Learning Management System (LMS)}

LMS merupakan aplikasi perangkat lunak berbasis web yang menggunakan basisdata sebagai tempat penyimpanan berbagai jenis informasi. LMS mengintegrasikan lingkungan pembelajaran interaktif dan menyediakan materi pembelajaran yang dapat disesuaikan dengan kebutuhan peserta didik dan pengajar [16].

LMS yang paling marak digunakan saat ini adalah Moodle. Di dalam Moodle, pengajar dan peserta didik dapat melakukan beberapa aktivitas terkait pembelajaran [14], misalnya mempelajari konsep melalui slide, gambar, video, animasi, membuat atau mengerjakan soal, berdiskusi, dan sebagainya.

\section{OpenSimulator}

OpenSimulator merupakan aplikasi server 3D berbasis open-source dengan fitur multi-platform dan multi-user. Aplikasi ini dapat digunakan untuk membuat lingkungan (dunia) virtual diakses melalui oleh klien dan mendukung banyak protokol komunikasi. OpenSimulator juga memiliki fasilitas atau fitur opsional (Hypergrid) yang memungkinkan pengguna mengunjungi instalasi OpenSimulator lain melalui web dari aplikasi viewer dan instalasi OpenSimulator-nya masing-masing [17] 
OpenSimulator ditulis dalam bahasa C\#, dapat berjalan pada sistem operasi Windows melalui framework .NET dan UNIX melalui framework Mono. OpenSimulator memiliki beberapa fitur, yaitu sebagai berikut [17] [18], (1) Merupakan platform open-source, yang memungkinkan pengguna untuk membuat, menyesuaikan, dan mengakses lingkungan virtual; (2) Mendukung lingkungan multi-user 3D secara online; (3) Mendukung interaksi secara realtime dalam aplikasi 3D; (4) Mendukung banyak protokol jaringan komunikasi, mengakses lingkungan virtual yang sama pada satu waktu menggunakan berbagai protokol; (5) Mendukung penulisan kode program ketika di dalam lingkungan virtual mencakup LSL/OSSL dan C\#; (6) Menyediakan fleksibilitas untuk menyesiaikan penerapan dunia virtual melalui penggunaan modul-modul plugin.

\section{E. MOODLE}

Moodle (Modular Object-Oriented Dynamic Learning Environment) merupakan perangkat lunak e-learning yang memungkinkan pengajar untuk membuat pembelajaran secara online dan mendukung interaksi antara pengajar dengan peserta didik. Moodle memungkinkan pengajar untuk menambahkan konten dan mengkombinasikan beragam aktivitas kedalam urutan skenario pembelajaran melalui alur pembelajaran yang terstruktur. Moodle juga memberikan konsep belajar dan eksperimen menjadi lebih menyenangkan sehingga memicu bertambahnya wawasan, kreativitas, dan inovasi [19]. Pada sisi fungsional, Moodle memiliki fitur yang dapat diatur untuk mengembangkan sistem penilaian, misalnya kuis dan ujian online [20].

\section{F. SLOODLE}

SLOODLE (Simulation Linked Object Oriented Dynamic Learning Environment) merupakan paket perangkat lunak yang mengintegrasikan lingkungan pembelajaran virtual berbasis web, yaitu Moodle dengan platform dunia virtual 3D, yaitu Second Life atau OpenSimulator. SLOODLE memadukan dua platform yang berbeda menjadi satu lingkungan pembelajaran virtual 3D/web. Semua aktifitas pembelajaran dapat dipadukan menggunakan kedua platform tersebut. Moodle yang sudah banyak digunakan dan cukup baik dalam penerapannya, dapat digunakan untuk mendukung kelas dunia virtual. Sedangkan Second life atau OpenSimulator dapat meningkatkan interaksi atau keterlibaan peserta didik yang lebih banyak yang kemudian direkam di dalam Moodle [21] [22].

\section{Metodologi PENELITIAN}

Penelitian ini dilakukan berdasarkan suatu framework. Penggunaan framework bertujuan untuk membantu dalam mengidentifikasi proses-proses serta aktivitas apa saja yang harus dilakukan untuk melaksanakan penelitian.

Rancangan penelitian ini mengadaptasi framework ADDIE [23] yang memiliki 5 tahap, yaitu analisis, perencanaan, pengembangan, implementasi, dan evaluasi. Tabel I merupakan pemaparan rancangan penelitian yang diadaptasi dari framework ADDIE secara lebih rinci.
TABEL I

RANCANGAN PENELITIAN

\begin{tabular}{|c|c|c|}
\hline Proses & Aktivitas & Luaran \\
\hline Analisis & - Analisis pengguna & $\begin{array}{l}\text { - Karakteristik } \\
\text { pengguna }\end{array}$ \\
\hline Perancangan & $\begin{array}{l}\text { Perancangan aktivitas } \\
\text { pembelajaran } \\
\text { Perancangan bahan } \\
\text { ajar } \\
\text { Perancangan sistem } \\
\text { Perancangan metode } \\
\text { pengujian } \\
\end{array}$ & $\begin{array}{l}\text { - Alur aktivitas } \\
\text { pembelajaran } \\
\text { - Perancangan materi } \\
\text { pembelajaran } \\
\text { - Dokumen arsitektur } \\
\text { sistem } \\
\text { - Skenario pengujian }\end{array}$ \\
\hline Pengembangan & $\begin{array}{l}\text { Pengembangan objek } \\
\text { dan konten } \\
\text { pembelajaran } \\
\text { Pengembangan } \\
\text { skenario pembelajaran } \\
\text { Pengembangan sistem } \\
\end{array}$ & $\begin{array}{l}\text { - Objek VLE } \\
\text { - Konten pembelajaran } \\
\text { - Skenario kegiatan } \\
\text { pembelajaran } \\
\text { - Sistem VLE }\end{array}$ \\
\hline Implementasi & $\begin{array}{l}\text { Instalasi } \\
\text { Distribusi } \\
\text { Pengelolaan aktivitas } \\
\text { pembelajaran }\end{array}$ & $\begin{array}{l}\text { - Pelaksanaan kegiatan } \\
\text { pembelajaran }\end{array}$ \\
\hline Evaluasi & $\begin{array}{l}\text { Uji penerimaan } \\
\text { pengguna } \\
\text { Uji hasil belajar }\end{array}$ & $\begin{array}{l}\text { - Tingkat penerimaan } \\
\text { pengguna } \\
\text { - Hasil belajar peserta } \\
\text { didik }\end{array}$ \\
\hline
\end{tabular}

\section{HASIL DAN PEMBAHASAN}

\section{A. Analisis}

Pada tahap ini diperoleh informasi mengenai karakteristik pengguna sistem yang dibedakan menjadi 3 pengguna utama, yaitu administrator, pengajar, dan peserta didik. Tabel II menunjukan interaksi yang dapat dilakukan oleh setiap pengguna terhadap sistem.

\section{TABEL II}

INTERAKSI PENGGUNA DENGAN SISTEM

\begin{tabular}{|c|l|}
\hline Pengguna & \multicolumn{1}{c|}{ Interaksi } \\
\hline \multirow{4}{*}{ Administrator } & - Mendaftarkan peserta didik \\
& - Meng-unggah bahan ajar \\
& Membuat kuis \\
& Membuat lingkungan virtual \\
& Mengelola objek virtual \\
& Memantau aktivitas peserta didik \\
\hline \multirow{5}{*}{ Pengajar } & Membuat bahan ajar \\
& - Meng-unggah bahan ajar \\
& - Membuat kuis \\
& Mendaftkarkan peserta didik \\
& Memantau aktivitas peserta didik \\
& Mengakses chat untuk melayani konsultasi \\
& dari peserta didik \\
\hline Peserta didik & Mengakses konten pembelajaran \\
& Mengikuti kuis \\
& Melihat hasil belajar \\
& Mengakses chat untuk konsultasi dengan \\
& pengajar \\
\hline
\end{tabular}




\section{B. Perancangan}

Pada tahap ini dilakukan perancangan aktivitas pembelajaran, arsitektur sistem, materi pembelajaran, perancangan sistem, dan skenario pengujian.

1) Rancangan alur aktivitas dan konten pembelajaran: Secara garis besar, sistem ini dibuat khusus untuk kegiatan pembelajaran yang dilakukan oleh pengajar dan peserta didik serta administrator. Oleh karena itu, alur pembelajaran pada sistem ini terdiri dari tiga aktivitas, yaitu alur proses pembelajaran untuk pengajar dan peserta didik serta alur pengelolaan sistem dan akun pengguna oleh administrator. Alur pembelajaran dikembangkan berdasarkan interaksi pengguna dengan sistem, seperti yang tertera pada Gambar 1.

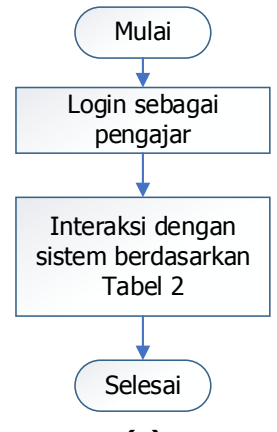

(a)

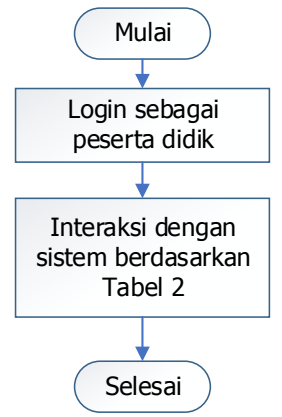

(b)

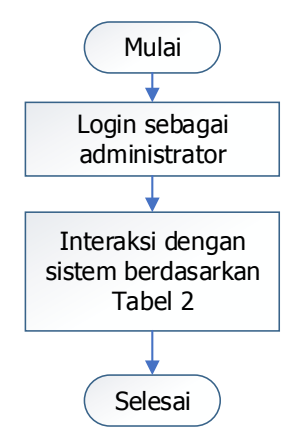

(c)

Gambar. 1 Diagram Aktivitas Pengguna: (a) Pengajar; (b) Peserta Didik; (c) Administrator

Pada penelitian ini, materi pembelajaran yang diterapkan dalam sistem adalah mata kuliah multimedia dengan sub-pokok materi audio atau suara. Materi ajar ini digunakan sebagai studi kasus untuk menerapkan sistem karena berdasarkan observasi, peserta didik merasa kurang tertarik untuk mempelajari materi ini. Hal ini disebabkan karena merupakan kombinasi dari berbagai rumpun ilmu, yaitu fisika, matematika, dan informatika sehingga peserta didik diharuskan memeiliki kemampuan berpikir kritis dan problem solving yang baik.

2) Rancangan Skenario Pengujian: Pada penelitian dilakukan dua pengujian terhadap sistem yang dikembangkan, yaitu pengujian hasil pembelajaran dengan melakukan pre-test dan post-test yang dibuat berdasarkan materi pembelajaran dan pengujian penerimaan pengguna dengan menggunakan model TAM (Technology Acceptance Model) [24]. Pengujian pre-test dan post-test dilakukan untuk mengetahui apakah terdapat perbedaan pada hasil belajar peserta didik. Untuk menginvestigasi hal tersebut, maka pada penelitian digunakan kelas kontrol dan eksperimen. Kelas kontrol merupakan kelas yang tidak diberi perlakukan penelitian secara khusus. Dengan kata lain kelas kontrol adalah kelas yang kegiatan pembelajarannya menggunakan proses pembelajaran secara konvensional, yaitu pengajar menjelaskan materi di dalam kelas. Sedangkan kelas eksperimen merupakan kelas yang dalam proses pembelajarannya memanfaatkan 3D VLE. Selain itu, pengujian juga dilakukan untuk menginvestigasi tingkat penerimaan pengguna terhadap 3D VLE yang dikembangkan. Pengujian ini mengadaptasi model TAM yang kemudian dikembangkan dalam bentuk kuesioner. Perolehan data kuesioner dilakukan berdasarkan rating scale yang terdiri 4 kategori, yaitu sangat setuju, setuju, tidak setuju, dan sangat tidak setuju. Kemudian kuesioner diberikan kepada peserta didik yang telah menggunakan sistem 3D VLE dalam melaksanakan proses pembelajaran. Model TAM memiliki beberapa variabel seperti yang ditunjukan pada Gambar 2 [24].

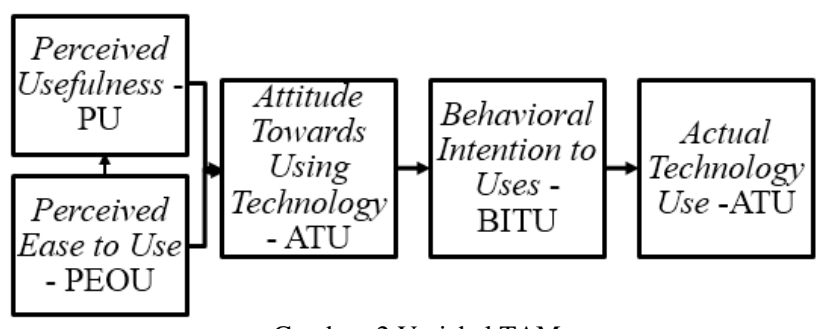

Gambar. 2 Variabel TAM

\section{Pengembangan}

Pada tahap ini semua komponen yang ada pada tahap perancangan direalisasikan sehingga dapat diimplementasikan untuk proses pembelajaran. Luaran dari tahap pengembangan ini adalah objek-objek VLE, konten pembelajaran, dan skenario pembelajaran.

1) Pengembangan Objek VLE: Secara umum, sistem VLE yang dikembangkan terdiri pengguna (baik administrator, pengajar, maupun peserta didik) yang direpresentasikan sebagai avatar serta objek lain seperti yang ada pada lingkungan belajar di dunia nyata, namun direpresentasikan secara virtual. Tabel III menunjukan interaksi antara pengguna dengan objek yang ada dalam 3D VLE.

TABEL III

AKTIVITAS PEMBELAJARAN DALAM 3D VLE

\begin{tabular}{|l|l|}
\hline \multicolumn{1}{|c|}{ Aktivitas } & \multicolumn{1}{c|}{ Objek 3D VLE } \\
\hline Administrasi & Reg-enroll booth \\
\hline $\begin{array}{l}\text { Konten } \\
\text { Pembelajaran }\end{array}$ & Presenter (Video/Slide) atau objek 3D lain \\
\hline Penilaian & $\begin{array}{l}\bullet \text { Quiz chair } \\
\text { • Papan skor }\end{array}$ \\
\hline Interaksi & $\begin{array}{l}\text { Chat } \\
\text { • Daftar pertemanan }\end{array}$ \\
\hline
\end{tabular}




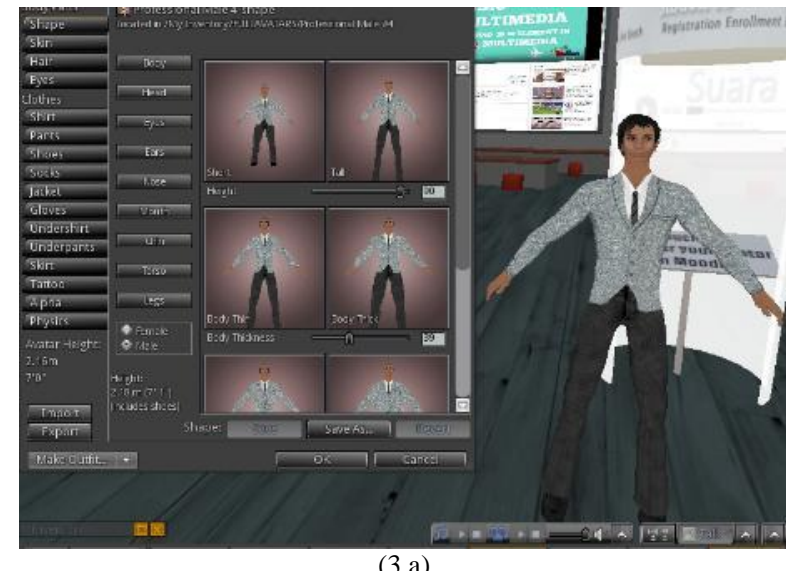

(3.a)

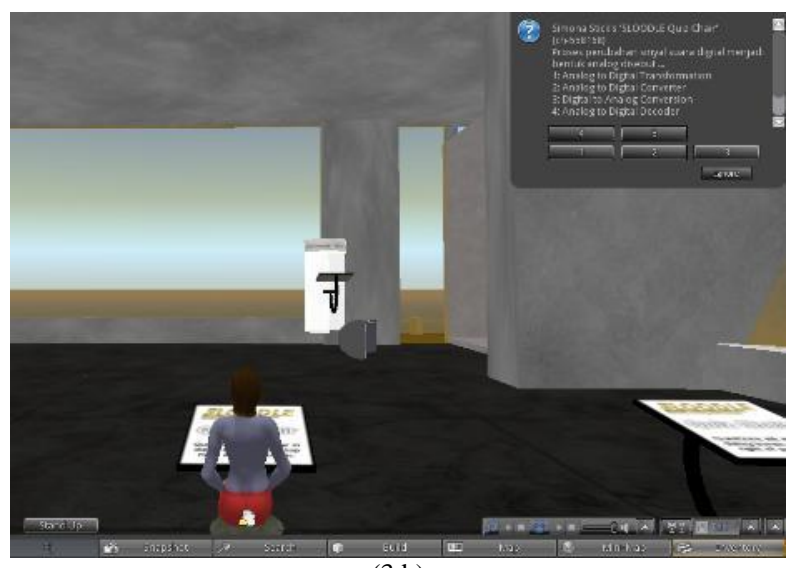

(3.b)

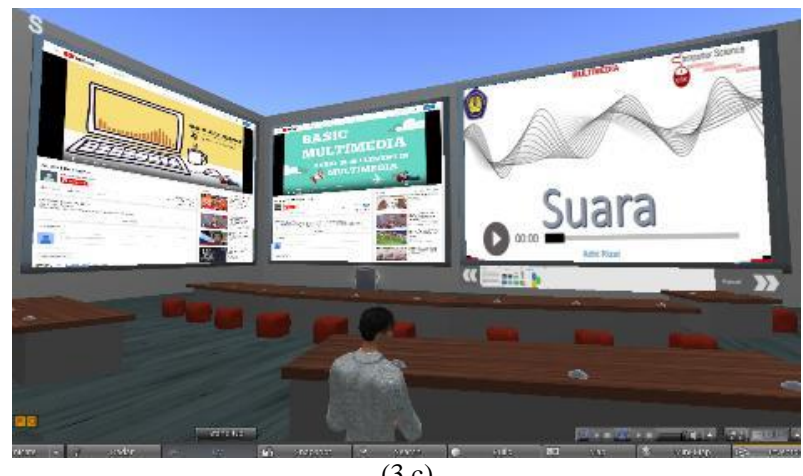

(3.c)

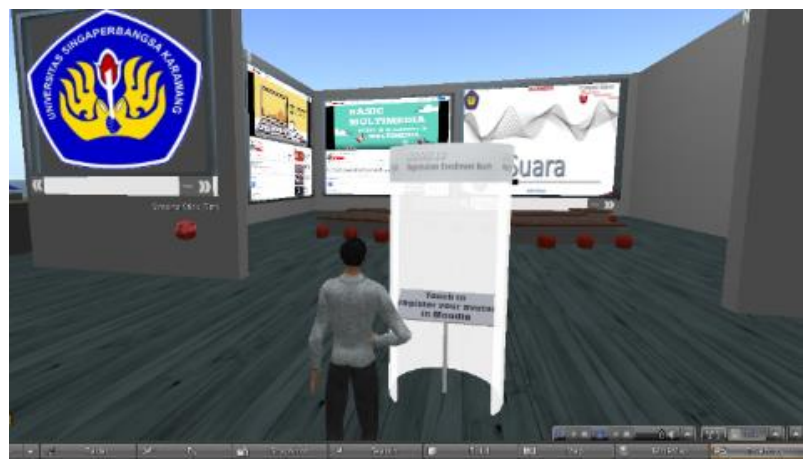

(3.d)

Gambar. 3 Objek-Objek 3D VLE
Gambar 3 menunjukan beberapa objek yang ada pada VLE. Gambar 3.a adalah avatar yang merupakan representasi dari pengguna. Pengguna dapat mengubah penampilan avatarnya masing-masing. Gambar 3.b merupakan objek Quiz chair yang menghubungkan kuis dari Moodle dan menampilkannya pada OpenSimulator dengan dua cara berbeda, yaitu dalam bentuk dialog atau chat. Ketika peserta didik duduk di atas Quiz chair dan sudah terdaftar dalam suatu topik pembelajaran, maka pertanyaan akan muncul sesuai dengan soal yang dibuat oleh pengajar di dalam Moodle. Quiz chair dalam OpenSimulator ini memiliki kelebihan dibandingkan dengan sistem pelaksanaan kuis/ujian pada umumnya, yaitu menerapkan konsep gamifikasi secara real-time. Peserta didik yang menjawab dengan benar suatu soal, maka Quiz chair akan bertambah ketinggiannya. Sedangkan jika peserta didik menjawab salah, maka posisi ketinggian Quiz chair tidak akan berubah. Gambar 3.c merupakan Presenter yang berfungsi untuk menampilkan konten atau materi pembelajaran di dalam OpenSimulator. Presenter dapat menampilkan konten multimedia seperti gambar, halaman web, dan video. Pada sistem VLE ini, digunakan dua jenis presenter, yaitu presenter untuk menampilkan slide dan presenter untuk menampilkan video pembelajaran. Presentasi dapat dilihat di dalam OpenSimulator dan atau di dalam Moodle itu sendiri. Presenter dapat diatur agar dapat digunakan oleh semua pengguna atau hanya administrator yang memiliki hak akses. Gambar 3.d merupakan Reg-enroll booth yang berfungsi sebagai tempat peserta didik melakukan pendaftaran agar dapat mengikuti pembelajaran tertentu. Setelah peserta didik mengakses Reg-enroll booth, maka akan muncul jendela dialog ( peserta didik untuk login ke dalam Moodle melalui browser. Setelah peserta didik berhasil melakukan login ke dalam Moodle, maka peserta didik harus mendaftarkan avatarnya ke dalam suatu course. Dengan cara ini, maka avatar yang terdapat pada OpenSimulator dapat terhubung dengan akun peserta didik di dalam Moodle.

2) Konten Pembelajaran: Konten pembelajaran yang diterapkan pada sistem 3D VLE dikembangkan sesuai dengan kurikulum atau silabus mata kuliah Multimedia dengan sub-pokok materi suara/audio. Selain itu, konten pembelajaran dikembangkan dalam bentuk slide dan video.

3) Skenario Pembelajaran: Skenario pembelajaran dibedakan menjadi dua, yaitu skenario pembelajaran untuk kelas kontrol dan kelas eksperimen. Pada kelas kontrol, kegiatan pembelajaran dilakukan dengan alur sebagai berikut: (1) Peserta didik mengerjakan soal pretest; (2) Pengajar menjelaskan materi pembelajaran di dalam kelas; (3) Peserta didik mengerjakan soal post-test. Sedangkan alur kegiatan pembelajaran pada kelas eksperimen yaitu sebagai berikut: (1) Peserta didik mengerjakan soal pre-test; (2) Peserta didik melakukan registrasi/login untuk masuk ke dalam kelas Multimedia melalui Reg-enroll booth; (3) Peserta didik mengakses materi pembelajaran melalui media presenter; (4) Peserta 
didik mengerjakan soal post-test; (5) Peserta melihat hasil penilaian (kuis) melalui objek papan skor.

\section{Implementasi}

Pada tahap ini sistem VLE yang telah dikembangkan kemudian diterapkan dalam proses pembelajaran sesuai dengan skenario pembelajaran.

1) Registrasi: Kegiatan pembelajaran peserta didik diawali dengan melakukan registrasi melalui reg-enroll booth seperti yang ditunjukan pada Gambar 4Error! Reference source not found. Proses registrasi ini bertujuan agar akun peserta didik pada OpenSimulator terintegrasi dengan akun pada Moodle, sehingga terdaftar pada course (mata pelajaran) pada Moodle dan dapat mengikuti kuis.

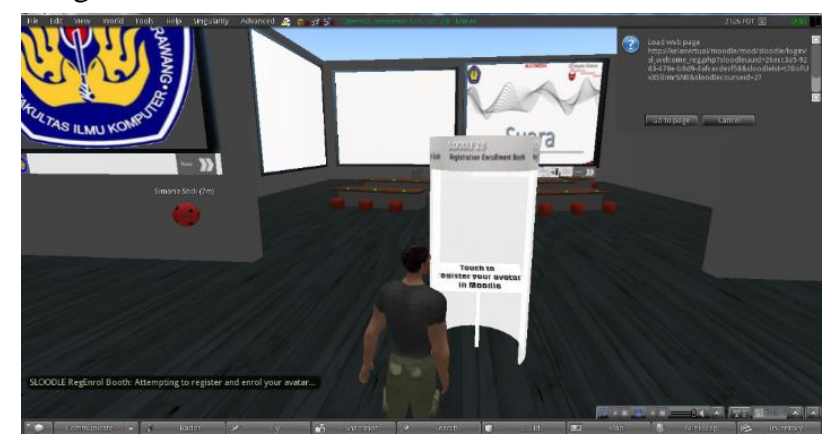

Gambar. 4 Aktivitas Registrasi Peserta Didik pada Kelas Virtual

2) Pembelajaran Pada Kelas Virtual: Setelah melakukan registrasi, peserta didik dapat mengakses media pembelajaran berupa slide presentasi dan video pembelajaran. Proses pembelajaran peserta didik pada kelas virtual dapat dilihat pada Gambar 5. Pada Gambar 5 terdapat 3 layar, satu layar berfungsi untuk menampilkan slide presentasi, sedangkan dua layar lainnya berfungsi untuk menampilkan video pembelajaran mengenai audio/suara.

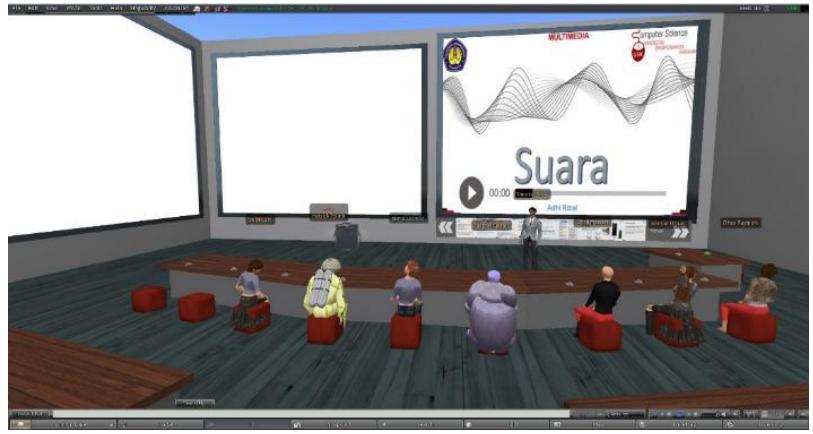

Gambar. 5 Aktivitas Belajar Peserta Didik pada Kelas Virtual

3) Evaluasi Hasil Belajar: Untuk mengetahui seberapa jauh peserta didik memahami materi pelajaran, maka dilaksanakan proses ujian. Pada proses ujian peserta didik harus menempati kursi yang telah disediakan di ruang kelas virtual yang berbeda dengan ruang kelas untuk belajar seperti yang ditunjukan oleh Gambar 6. Setelah peserta didik duduk di kursi ujian, maka soal ujian akan muncul di sudut kanan atas layar. Jika peserta didik menjawab soal dengan benar, maka ketinggian kursi yang ditempatinya akan bertambah dan muncul notifikasi "benar". Tetapi jika peserta didik salah dalam menjawab soal ujian, maka kursi yang ditempatinya tidak akan bergerak (tetap). Peserta didik akan turun dari kursi yang ditempatinya secara otomatis ketika semua soal ujian berhasil dikerjakan. Setelah peserta didik mengerjakan ujian, maka peserta didik dapat melihat hasil atau nilai ujiannya pada papan skor seperti yang ditunjukan pada Gambar 7. Data peserta didik dan nilai yang ada papan skor akan diperbarui secara otomatis setiap 60 detik. Dengan adanya fitur ini peserta didik yang terlambat menyelesaikan ujiannya tetap dapat melihat hasilnya.

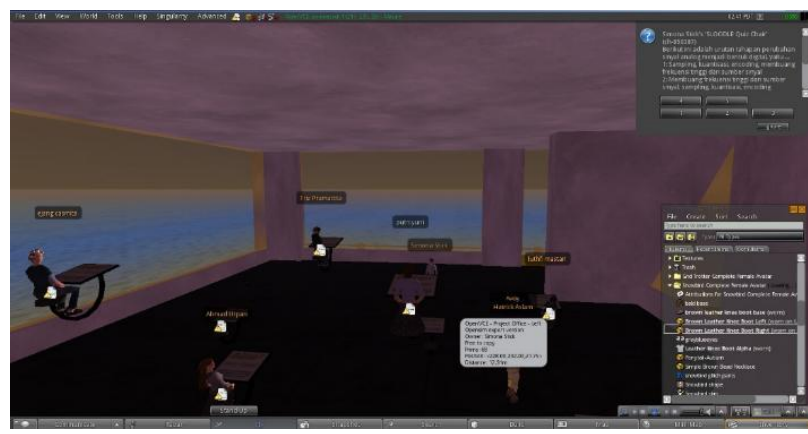

Gambar. 6 Aktivitas Ujian Peserta Didik pada Kelas Virtual

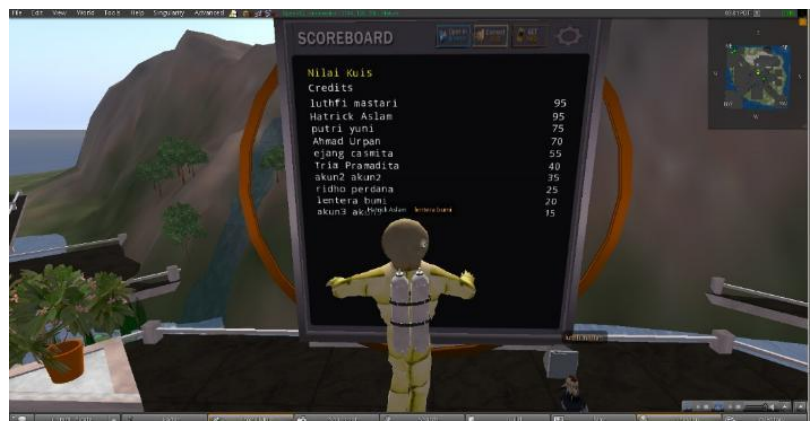

Gambar. 7 Papan Skor Hasil Ujian

\section{E. Evaluasi}

Evaluasi dilakukan dengan melakukan analisis terhadap hasil pre-test dan post-test pada mata kuliah multimedia dengan sub-pokok Audio/Suara dari kelas kontrol dan kelas eksperimen. Kelas kontrol dan eksperimen masingmasing berjumlah 12 dan 11 peserta didik dari dua kelas yang berbeda. Selain itu evaluasi juga dilakukan dengan melakukan analisis terhadap hasil kuesioner TAM yang diperoleh dari masing-masing peserta didik pada kelas kontrol.

1) Analisis Hasil Belajar Peserta Didik: Hasil belajar peserta didik diperoleh dari nilai pre-test dan post-test kelas eksperimen dan kelas kontrol. Pada penelitian ini nilai pre-test dan post-test peserta didik memiliki rentang 0 - 100. Gambar 8 (a) menunjukan nilai rata-rata pre-test dan post-test dari kelas kontrol dan kelas eksperimen. Kelas kontrol memperoleh nilai rata-rata pre-test sebesar 
25,4. Sedangkan kelas eksperimen memperoleh nilai ratarata pre-test sebesar 33,2. Perolehan nilai tersebut menunjukan bahwa kelas eksperimen memiliki nilai ratarata pre-test yang lebih tinggi dibandingkan dengan kelas kontrol.

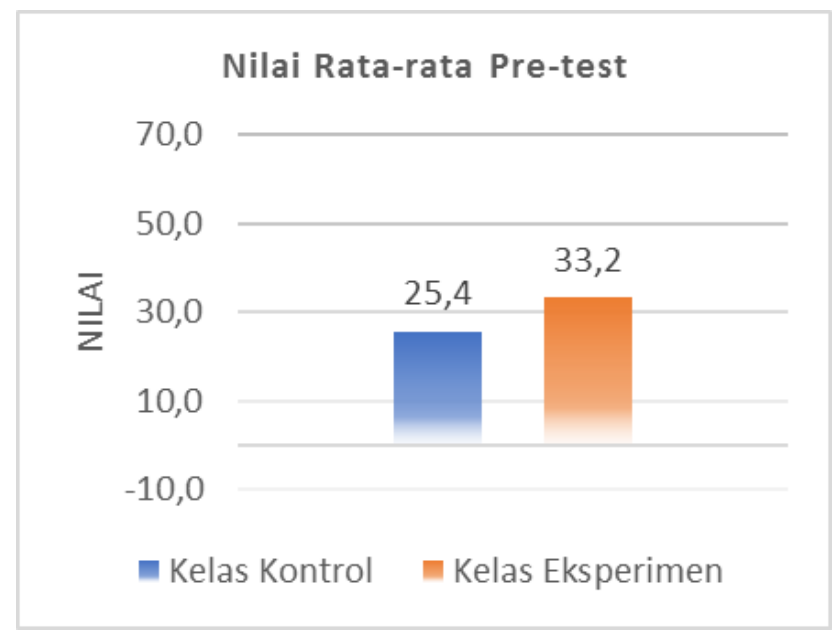

(a)

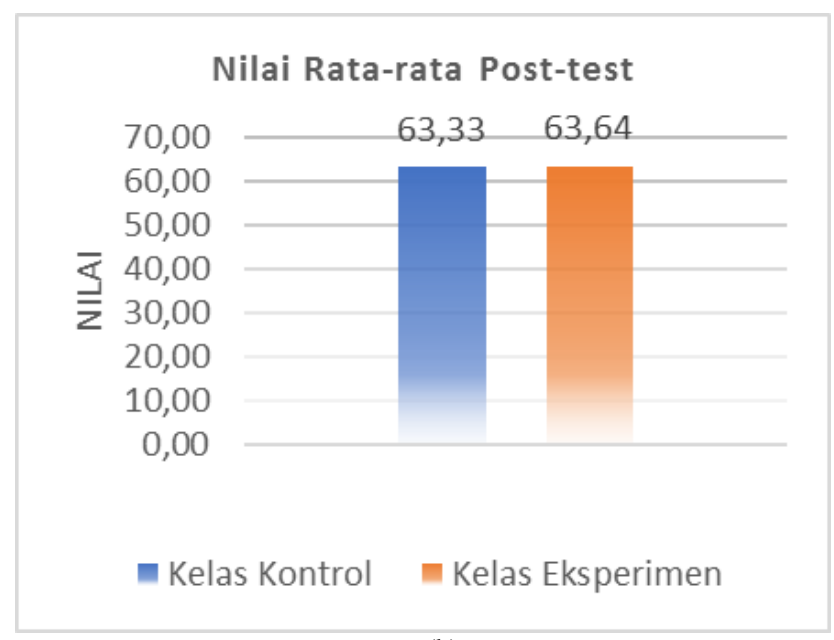

(b)

Gambar. 8 Nilai Rata-Rata Pre-test dan Post-test

Selain itu, berdasarkan Gambar 8 (b) kelas kontrol memperoleh nilai rata-rata post-test sebesar 63,33. Sedangkan kelas eksperimen memperoleh nilai rata-rata post-test sebesar 63,64. Perolehan nilai tersebut menunjukan bahwa kelas eksperimen memiliki nilai ratarata post-test yang lebih tinggi dibandingkan dengan kelas kontrol.

Berdasarkan data tersebut, maka perbedaan rata-rata nilai pre-test dan post-test (gain) dari dua kelompok kelas dapat dilihat pada Gambar 9. Gambar 9 menunjukan bahwa kelas eksperimen memiliki gain sebesar 0,46. Sedangkan kelas kontrol memiliki gain yang lebih tinggi dibandingkan dengan kelas eksperimen, yaitu sebesar 0,51.

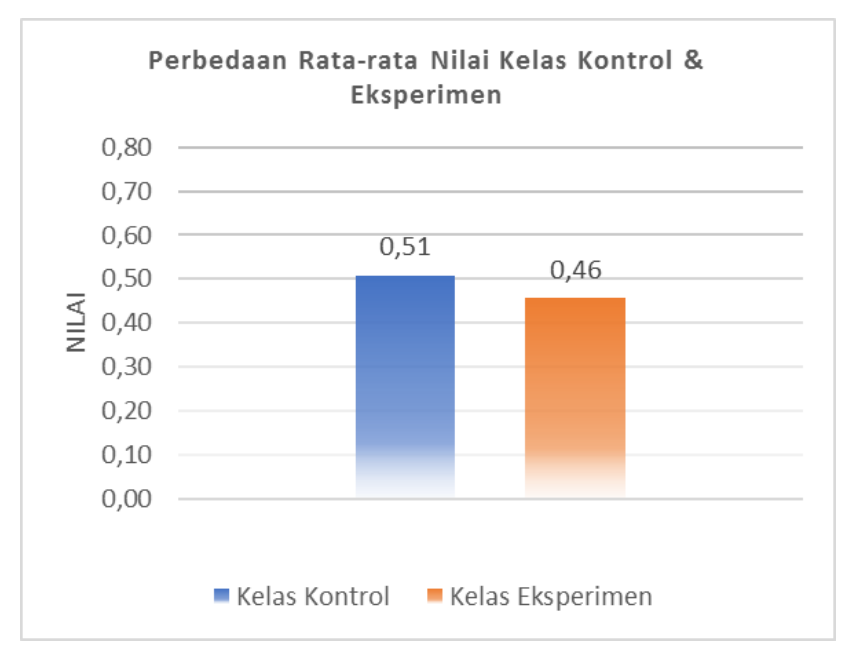

Gambar. 9 Perbedaan Rata-Rata (Gain) Nilai Kelas Kontrol dan Eksperimen

Berdasarkan Gambar 8 dan Gambar 9, maka yang dilakukan berikutnya adalah uji hipotesis untuk menginvestigasi apakah pembelajaran menggunakan sistem yang diusulkan berdampak signifikan terhadap peningkatan hasil belajar. Pengujian dilakukan menggunakan Uji t-2 sampel independen dengan kriteria hipotesis sebagai berikut: $\mathrm{H}_{0}=$ tidak ada perbedaan peningkatan hasil belajar antara kelas eksperimen dengan kelas kontrol; $\mathrm{H}_{1}=$ terdapat perbedaan peningkatan hasil belajar antara kelas eksperimen dengan kelas kontrol. Dengan kata lain jika nilai signifikansi lebih besar dari 0,05, maka $\mathrm{H}_{0}$ diterima dan $\mathrm{H}_{1}$ ditolak, sedangkan jika nilai signifikansi lebih besar dari 0,05 maka $\mathrm{H}_{0}$ ditolak dan $\mathrm{H}_{1}$ diterima.

\begin{tabular}{|c|c|c|c|c|}
\hline & \multicolumn{2}{|c|}{ Nilai Ujian } \\
\hline & & & $\begin{array}{c}\text { Equal } \\
\text { variances } \\
\text { assumed }\end{array}$ & $\begin{array}{c}\text { Equal } \\
\text { variances not } \\
\text { assumed }\end{array}$ \\
\hline \multirow{2}{*}{$\begin{array}{l}\text { Levene's Test for } \\
\text { Equality of } \\
\text { Variances }\end{array}$} & \multicolumn{2}{|l|}{$\mathrm{F}$} & 1.785 & \\
\hline & \multicolumn{2}{|l|}{ Sig. } & .196 & \\
\hline \multirow{8}{*}{$\begin{array}{l}\text { t-test for Equality } \\
\text { of Means }\end{array}$} & \multirow{3}{*}{\multicolumn{2}{|c|}{$\begin{array}{l}\text { t } \\
\text { df } \\
\text { Sig. (2-tailed) }\end{array}$}} & 1.131 & 1.108 \\
\hline & & & 21 & 16.262 \\
\hline & & & & 284 \\
\hline & \multicolumn{2}{|l|}{ Mean Difference } & & \\
\hline & \multicolumn{2}{|c|}{ Std. Error Difference } & & \\
\hline & & & 6.597 & 6.736 \\
\hline & \multirow{2}{*}{$\begin{array}{l}95 \% \text { Confidence } \\
\text { Interval of the } \\
\text { Difference }\end{array}$} & Lower & -6.258 & -6.800 \\
\hline & & Upper & 21.182 & 21.724 \\
\hline
\end{tabular}

Gambar. 10 Hasil Uji-t 2 Sampel Independen

Gambar 10 menunjukan bahwa nilai Sig. (2-tailed) diperoleh adalah sebesar 0,271 dan lebih besar dari 0,05. Berdasarkan hal ini maka $\mathrm{H}_{0}$ ditolak dan $\mathrm{H}_{1}$ diterima, atau dengan kata lain tidak terdapat perbedaan peningkatan hasil belajar antara kelas eksperimen dengan kelas kontrol. 
Berdasarkan temuan selama penelitian, terdapat beberapa faktor yang menyebabkan tidak adanya perbedaan peningkatan hasil belajar terhadap kedua kelompok. Faktor pertama adalah disebabkan oleh tingkat perbedaan perolehan nilai pre-test yang signifikan dari kelas eksperimen dan kelas kontrol yaitu sebesar 7,8, sedangkan perolehan nilai post-test pada kedua kelompok kelas tidak jauh berbeda, yaitu sebesar 0,31. Selain itu, selama proses pembelajaran, peserta didik pada kelas eksperimen lebih banyak menghabiskan waktunya untuk melakukan eksplorasi sistem lingkungan virtual serta memodifikasi avatarnya masing-masing. Hal ini menyebabkan peserta didik kehilangan fokus dalam melaksanakan kegiatan pembelajaran.

2) Analisis uji TAM: Hasil uji penerimaan pengguna berdasarkan TAM disajikan pada Tabel IV. Setelah dilakukan perhitungan, maka nilai yang diperoleh kemudian diklasifikasikan untuk memudahkan dalam menyimpulkan kriteria penerimaan pengguna terhadap sistem yang diterapkan. Klasifikasi hasil jawaban responden terdiri dari 4 kategori, seperti yang ditunjukan pada Gambar 10 [25].

TABEL IV

HASIL KUESIONER TAM

\begin{tabular}{|l|r|}
\hline \multicolumn{1}{|c|}{ Variabel } & \multicolumn{1}{c|}{ Nilai } \\
\hline Perceived Usefulness (PU) & 87,273 \\
\hline Perceived Ease-of-Use (PEOU) & 87,273 \\
\hline Attitude Toward Using (ATU) & 89,697 \\
\hline Behavioral Intention to Use (BITU) & 87,879 \\
\hline Actual Use (AU) & 89 \\
\hline Rata-rata & $\mathbf{8 8 , 2 4 2}$ \\
\hline
\end{tabular}

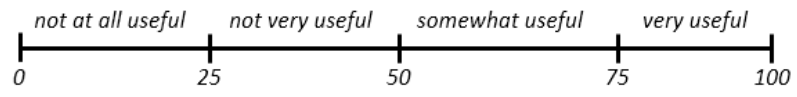

Gambar. 11 Kategori Rating-Scale

Berdasarkan Tabel IV, rata-rata dari perolehan nilai semua variabel TAM adalah 88,242. Jika dilihat pada Gambar 11, maka tingkat penerimaan pengguna berada pada kategori very usefull. Dengan kata lain, sistem pembelajaran yang dikembangkan dapat memberikan nilai kepuasan yang tinggi dan diterima untuk digunakan oleh peserta didik dalam kegiatan pembelajaran.

\section{KESIMPULAN}

Penelitian ini berhasil mengembangkan kelas virtual berbasis dunia virtual 3 dimensi menggunakan framework ADDIE. Kelas virtual dikembangkan sesuai dengan sarana dan prasarana yang ada di kelas yang sebenarnya. Peserta didik dapat berinteraksi dengan objek-objek yang ada di dalam kelas virtual untuk melaksanakan kegiatan pembelajaran, yaitu objek reg-enroll booth, presenter (video/slide), quiz chair, papan skor, chat, dan daftar pertemanan.
Berdasarkan pengujian terhadap hasil belajar peserta as didik, penerapan kelas virtual tidak berpengaruh besar terhadap proses belajar peserta didik. Hal ini ditandai dengan perolehan nilai gain hasil belajar pada kelas yang menggunakan kelas virtual lebih rendah dibandingkan dengan kelas dengan pembelajaran konvensional. Selain itu perolehan hasil uji- $t$ juga membuktikan bahwa tidak terdapat perbedaan peningkatan hasil belajar antara peserta didik yang menggunakan kelas virtual dengan yang tidak menggunakan. Hal ini disebabkan karena konsentrasi atau fokus peserta didik yang teralihkan oleh lingkungan virtual yang dapat dieksplorasi secara luas dan avatar yang dapat dimodifkasi. Walaupun demikian, berdasarkan hasil uji penerimaan pengguna, kelas virtual yang dikembangkan memberikan kepuasan bagi pengguna dan dapat diterima untuk digunakan oleh peserta didik.

\section{PENELITIAN BERIKUTNYA}

Untuk penelitian berikutnya, kelas virtual harus dapat digunakan dengan mengintegrasikan metode pembelajaran yang sesuai sehingga konsentrasi peserta didik tidak terpecah ketika kegiatan pembelajaran berlangsung. Salah satu solusi yang dapat diterapkan misalnya dengan menggunakan metode penyajian konten pembelajaran berbasis video singkat atau microlecture. Selain itu penelitian berikutnya juga dapat dilakukan dengan mengembangkan objek 3D lain yang dapat digunakan sebagai simulasi, misalnya pengembangan laboratorium virtual sebagai alternatif kegiatan praktikum di laboratorium yang sebenarnya.

\section{UCAPAN TERIMA KASIH}

Penelitian ini didanai dari Hibah Penelitian Dikti tahun 2018. Oleh karena itu Penulis mengucapkan terimakasih kepada Dikti dan juga pihak-pihak terkait yang telah mendukung kami dalam penyelesaian penelitian ini.

\section{REFERENSI}

[1] I. Simonics, " Changing of multimedia elements in eLearning development," dalam Emerging eLearning Technologies and Applications (ICETA), 2013.

[2] G.-J. Hwang, "Definition, framework and research issues of smart learning environments - a context-aware ubiquitous learning perspective," Smart Learning Environment, pp. 1-14, 2014.

[3] H.-C. H. G.-J. Chu dan C.-C. Tsai, "A knowledge engineering approach to developing mindtools for context-aware ubiquitous learning," Computers \& Education, pp. 289-297, 2010.

[4] R. D. Miller, Developing 21st century skills through the use of student personal learning networks, Scottsdale: Northcentral University, 2009.

[5] P. f. 2. C. S. "P21 Partnership For 21st Century Learning," 2008. [Online $]$. http://files.eric.ed.gov/fulltext/ED519337.pdf.

Available:

[6] I. Yengin, “ Using educational technology to create effective learning societies in 21st century," Information Technology Based Higher Education and Training (ITHET), pp. 1-7, 2014.

[7] M. Achiruzaman dan Y. Rosmansyah, "A framework for 3D virtual game using MOODLE, SLOODLE and Open Simulator: Case Study: Training of house building data collecting by National Statistical Office (NSO), Government Agency, BPS Statistics Indonesia," dalam 2016 International Conference on 
Information Technology Systems and Innovation (ICITSI), Bandung, 2016.

[8] M. Chau, A. Wong, M. Wang, S. Lai, K. W. Chan, T. M. Li, D. Chu, I. K. Chan dan W.-k. Sung, "Using 3D virtual environments to facilitate students in constructivist learning," Decision Support Systems 56 (2013), pp. 115-121, 2013.

[9] D. Livingstone dan J. Kemp, “ Integrating Web-Based and 3D Learning Environments: Second Life Meets Moodle," CEPIS UPGRADE: European Journal for the Informatics Professional, pp. 8-14, 2008.

[10] B. Mennecke, E. M. Roche, D. A. Bray, Konsynski, Benn, Lester, John, Rowe, Michael, Townsend dan A. M., "Second Life and Other Virtual worlds: A Roadmap for Research," dalam 28th International Conference on Information Systems (ICIS), 2007, 2007.

[11] J. Carey, "Expressive communication and social conventions in virtual worlds," ACM SIGMIS Database: the DATABASE for Advances in Information Systems, pp. 81-85, 4 November 2007.

[12] O. Ak dan B. Kutlu, "Comparing 2D and 3D game-based learning environments in terms of learning gains and student perceptions," British Journal of Educational Technology, vol. 48, no. 1, pp 129-144, 2015

[13] S. E. August, M. L. Hammers, D. Brian Murphy, A. Neyer, P. Gueye dan R. Q. Thames, " Virtual Engineering Sciences Learning Lab: Giving STEM Education a Second Life," IEEE Transactions on Learning Technologies, vol. 9, no. 1, pp. 18-30, 2016.

[14] Y. Rosmansyah dan H. Ashaury, "A 3D multiuser virtual learning environment and learning management system," dalam 6th International Conference on Electrical Engineering and Informatics (ICEEI), Langkawi, 2017.

[15] D. D. I. "Designing Digitally," 2012. [Online]. Available: http://www.designingdigitally.com/whitepapers/corporatetraining-using-3d-serious-games-and-3d-training-simulations.

[16] D. Ifenthaler, "Learning management systems," dalam Encyclopedia of the sciences of learning, New York, Springer, 2012, pp. 1925-1927.

[17] OpenSimulator, "About Us: OpenSimulator," 24 January 2017. [Online]. Available: http://OpenSimulator.org/.

[18] D. Chao, T. Kanno dan K. Furuta, "Experimental study on tourist satisfaction using participatory simulation in a virtual environment," Springer Plus, 2013.

[19] R. Dvorak, Moodle for Dummies, Indianapolis: Wiley Publishing, Inc., 2011.

[20] R. El Bahsh dan M. I. Daoud, "Evaluating the Use of Moodle to Achieve Effective and Interactive Learning: A Case Study at the German Jordanian University," dalam The 2nd International Conference on Open Source Software Computing (OSSCOM 2016), Lebanon, 2016.

[21] Eduserv, "Online Learning in Virtual Environments with SLOODLE," University of the West of Scotland, 2009.

[22] N. Pellas dan A. Boumpa, "Open Sim and Sloodle integration for pre-service foreign language teachers' continuing professional development: A comparative analysis of learning effectiveness using the Community of Inquiry Model," Journal of Educational Computing Research, pp. 1-34, 2015.

[23] C. Peterson, "Bringing ADDIE to Life: Instructional Design at Its Best," Journal of Educational Multimedia and Hypermedia, pp. 227-241, 2003.

[24] A. Wahyudin, Munir dan S. Soviani, "Tingkat Penerimaan Media Video Conference dalam Proses Pembelajaran dengan menggunakan Technology Accepted Model (TAM)," Jurnal Pendidikan Teknologi Informasi Dan Komunikasi, 2011.

[25] A. Rizal, R. Ibnu Adam dan Susilawati, "Pengembangan Laboratorium Virtual Fisika Osilasi," Jurnal Online Informatika, pp. 55-60, 2018. 